\title{
Authentic Materials in Reading Comprehension Classroom: Its Effectiveness to Indonesian EFL Students' Achievement
}

\author{
Muhammad Azwar Assiddiq \\ English Language Education Study Program, Faculty of Teacher Training and Education, Khairun University, Maluku Utara, 97735, Indonesia \\ azwarassiddiq@unkhair.ac.id \\ *Corresponding Author \\ Whatsapp Number: [+6285242047101]
}

How to Cite : Assiddiq, M., A. (2019). Authentic Materials in Reading Comprehension Classroom: Its Effectiveness to Indonesian EFL Students' Achievement. International Journal for Educational and Vocational Studies, 1 (7), 707-712

\section{ARTICLE HISTORY}

Received:11August 2019

Revised: 22 September 2019

Accepted: 19 October 2019

\section{KEYWORDS}

Authentic Material; Reading Comprehension; Reading Motivation;

\section{ABSTRACT}

The study was aimed to finding out (1) Whether or not the use of authentic materials is effective to develop the reading comprehension achievement of Indonesian EFL Students, (2) Whether or not the use of authentic materials is effective to develop reading motivation of Indonesian EFL Students. The study was carried out under the quantitative paradigm with quasi experimental design. The participants were selected by using cluster sampling technique and divided into two groups, namely authentic group and pedagogic group. Each of groups consisted of 39 participants. All participants were first grade students of high school in Bone, Indonesia. The data of the students' reading comprehension achievement were collected by using reading comprehension test, while the data about the students' reading motivation were taken from Motivation for Reading Questionnaire (MRQ) containing 32 items on seven domains of motivation. The data collected were then analyzed through descriptive and inferential statistics through SPSS 20 program. The result showed that (1) the use of authentic materials was effective than pedagogic materials to develop reading comprehension achievement of the first year students. It was seen from the significance t-test result that reveals the significance value was lower than the significance level; $(0.00<0.05)$. Furthermore, in relation to the reading motivation of students, $(2)$ it was found that authentic materials was effective to develop students' reading motivation. The result showed that the p-value of students' reading motivation before and after treatments was greater than the level of significance $(0.00<0.05)$.

This is an open access article under the CC-BY-SA license.

\section{INTRODUCTION}

Reading is a fundamental skill that should be mastered by the students to make them successful in learning, because most of the learning processes involve reading. The reading ability extremely influences the students' ability to comprehend the subject matter. By reading, the students can grasp the idea or information from books, magazines, internet and other sources of learning. On the other hand, reading is also important for students' self-development. The students can expand their knowledge, enrich their experience and develop their thinking and creativity by reading (Daar, 2019; Fitriani et al., 2019; Noviandari \& Mursidi, 2019).

Indeed, reading process does not only focus on how to read a text but also focuses on how to comprehend it. As a reader the students must be able to comprehend the English passages that are presented as written text (Marzuki, 2019). The students' comprehension ability will guide them to understand the text hence they can get the - given information in the text, whether the information is explicitly or implicitly stated. It makes Reading comprehension become the most important thing to be focused on teaching reading activity (Fitriani et al., 2019).

In the conventional methods of teaching reading comprehension, the teachers, for the most part, teach just through textbooks that are not interesting for students. Therefore, EFL students confront some problems in their reading comprehension as a result of factors such as reading strategies, lack of motivation and absence of good materials. Consequently, EFL teachers have to engage different materials with the intention to be interesting, up-to-date and efficient. These can be overcome by integrating authentic materials in teaching reading comprehension.

Authentic material is the material that has been created to accomplish some social purposes in the language community (Peacock, 1997), while Nunan (1989) defined authentic material as spoken or written material which is 
not aimed to be applied in teaching. In addition Richards (2001) revealed that the language used in the classroom must represent the language used in the real world. Based on those definitions, it can be said that the authentic materials are materials which are not designed to teaching and learning process but they can be used for it.

Studies demonstrated that there are some benefits of using authentic materials in the classroom, they are: original, interesting, motivating and useful (Peacock, 1997). Authentic materials can confirm for students the direct link between the foreign language classroom and the world outside the classroom. Moreover, Melvin and Stout (1987) stated that using authentic materials can increase the motivation of students to learn a foreign language and their interests in the subject matters. Furthermore, they confirm that such students obtain more confidence when they work with authentic materials.

When dealing with authentic materials, one that should be bear in mind is the use of the authentic materials should be done with a purpose. It needs to have a clear pedagogic goal for what precisely the teacher goes the students to learn from the materials. The role of the teacher is needed to make the students confident when handling authentic materials. Berardo (2006) gives possible solution which is to give text related tasks. There are three basic types of reading activities: (1) Pre-reading. This activity is used to activate existing schemata or background knowledge of the students. It also provides information of linguistic or social-cultural inadequacy to prepare the students for reading the text. (2) While-reading. It is used to encourage the students to be a flexible and active reader also to promote an interaction between reader and writer. (3) Post-reading. This activity often comes as questions that follow a text. It is used to test understanding.

Regardless of many studies performed in this field, however, some difficulties are still faced by Indonesian EFL students in reading comprehension. Hence, this study aimed at investigating the effectiveness of using authentic materials in developing reading comprehension achievement and reading motivation of Indonesian EFL students.

\section{METHODS}

\subsection{Research Design and Participants}

This conducted study applied an experimental method that emphases on quasi-experimental design. The participants were selected by using cluster sampling technique and divided into two groups, namely authentic group and pedagogic group. Each of groups consisted of 39 participants. All participants were first grade students of high school in Bone, Indonesia. The participants were native speakers of Indonesian and ranged between 16 and 18 years in age. They formed up a representative sample of Indonesian EFL students.

\subsection{Research Instruments}

Two kinds of instruments were applied in this study. They were reading comprehension test to measure reading comprehension achievement of the EFL students, and Motivation for Reading Questionnaire (MRQ) to know the motivation of EFL students in learning reading comprehension using authentic materials. Reading comprehension test was in multiple choice form and the total number of the questions was 30 items. MRQ was adopted from Wigfield and Guthrie (1997). However, in this study, the researcher only chose 32 items of the total 53 items in the questionnaire because only seven domains of total eleven domains of reading motivation were considered to measure, they were: reading efficacy, reading challenge, reading curiosity, reading involvement, reading work avoidance, reading competition, and reading for grades. Furthermore, the items of the questionnaire were translated into Indonesian language to avoid mis understanding and misinterpreting of the students.

\subsection{Procedure}

This study lasted over for 6 weeks or 12 class meetings. In the first meeting, the reading comprehension test was given to the authentic and pedagogic group. After that, both groups went through 10 meetings of treatments. The participants in the authentic group were treated by authentic materials which were taken from newspapers, magazines, and online articles while the participants in the pedagogic group were treated by pedagogic materials taken from textbooks. Finally, in meeting 12, the posttest was administered to the participants. To get data about the participants' reading motivation, MRQ was distributed in the authentic group before and after treatments were conducted. After collecting the data by distributing the reading comprehension test and MRQ to the participants, the data were analyzed using Statistical Package for Social Sciences (SPSS) program version 20.0.

\subsection{Data Analysis}

\subsubsection{Reading Comprehension Test}

The data collected from reading comprehension test was analyzed by using the following procedures:

a. Scoring the students' answers of pretest and posttest. Each of students' correct answer got 10 and wrong answer got 0 . The formula for indicating the students' score as follows:

$$
\text { Score }=\frac{\text { Obtained Score }}{\text { Maximum Score }} \times 100
$$

b. After tabulating the students' scores, the researcher classified of the students' score based on the following table 1 of rating scale. 
Table 1. Scoring Classification of Students' Reading Achievement

\begin{tabular}{ccc}
\hline \multicolumn{1}{l}{ No } & Score & Classification \\
\hline 1 & $86-100$ & Very Good \\
2 & $71-85$ & Good \\
3 & $56-70$ & Average \\
4 & $41-55$ & Poor \\
5 & $<40$ & Very Poor \\
\hline
\end{tabular}

(Depdiknas in Hasriani, 2013)

c. Calculating the mean score, standard deviation, t-test value, and significant difference between pretest and posttest, they were analyzed using SPSS program version 20.0 .

\section{$2.5 \mathrm{MRQ}$}

Calculating the mean score, standard deviation, t-test value, and significant difference between pretest and posttest, they were analyzed using SPSS program version 20.0 .

\section{RESULTS AND DISCUSSION}

\subsection{Reading Comprehension Development of Indonesian EFL Students}

This part covers the reading comprehension achievement of the authentic and pedagogic group before and after learning reading comprehension using authentic and pedagogic materials. After scoring the reading comprehension of the participants and then analyzing the data through descriptive statistics, the data analysis results were found and those were described based on the frequency, percentage, mean score and standard deviation as seen in the subsequent section.

\subsubsection{Description for Pretest Scores of the Authentic and Pedagogic Group}

Table 2. the Rate Frequency and Percentage Distribution of Pretest Scores

\begin{tabular}{ccccc}
\hline \multirow{2}{*}{ Classification } & \multicolumn{2}{c}{ Authentic Group } & \multicolumn{2}{c}{ Pedagogic Group } \\
\cline { 2 - 5 } & $\mathrm{F}$ & $\%$ & $\mathrm{~F}$ & $\%$ \\
\hline Very Good & 0 & 0.00 & 0 & 0.00 \\
\hline Good & 0 & 0.00 & 1 & 2.56 \\
\hline Average & 18 & 46.15 & 15 & 38.46 \\
\hline Poor & 20 & 51.28 & 20 & 51.28 \\
\hline Very Poor & 1 & 2.56 & 3 & 7.69 \\
\hline Total & 39 & $100 \%$ & 39 & $100 \%$ \\
\hline
\end{tabular}

Table 2 shows the frequency and percentage for the participants pretest scores in the authentic and pedagogic group. Based on Table 2, a large frequency and percentage of the participants were at poor level. In fact, 20 participants (51.28\%) in authentic group gained score categorized as poor. Others 18 participants (46.15\%) received score classified as average, and none of them could reach good and very good score. On the other hand, there was only 1 participant $(2.56 \%)$ who got very poor score.
Comparable at the authentic group, majority of the participants in the pedagogic group had poor ability in reading comprehension. The facts indicated that 20 participants $(51.28 \%)$ could only get score categorized as poor, and other 3 participants (7.69\%) got score categorized as very poor. Otherwise, there was merely 1 participant (2.56\%) who could reach score categorized as good and 15 participants (38.46\%) obtained average score. Based on the data description, it could be revealed that participants of the two groups had the same ability level in reading comprehension before treatments were conducted. Both groups were classified as poor.

To support or strengthen the previous data description, the researcher also measured the mean scores and standard deviation of the participants' pretest scores in Table 3.

Table 3. the Mean Score and Standard Deviation of Participants' Pretest Scores

\begin{tabular}{ccc}
\hline Group & Mean Score & Standard Deviation \\
\hline Authentic & 54.33 & 7.56 \\
\hline Pedagogic & 54.00 & 7.77 \\
\hline
\end{tabular}

As can be observed in Table 3, the pretest mean score of the authentic group ( $\mathrm{MS}=54.33, \mathrm{SD}=7.56)$ was quiet same with the pretest mean score of the pedagogic group (MS=54.00, $\mathrm{SD}=7.77$ ) and they were categorized as poor. From these results, it was assumed that the two groups were similar in terms of their reading comprehension achievement before the treatments were applied.

\subsubsection{Description for Posttest Scores of the Authentic and Pedagogic Group}

Table 4. the Rate Frequency and Percentage Distribution of Posttest Scores

\begin{tabular}{ccccc}
\hline \multirow{2}{*}{ Classification } & \multicolumn{2}{c}{ Authentic Group } & \multicolumn{2}{c}{ Pedagogic Group } \\
\cline { 2 - 5 } & $\mathrm{F}$ & $\%$ & $\mathrm{~F}$ & $\%$ \\
\hline Very Good & 2 & 5.13 & 1 & 2.56 \\
\hline Good & 16 & 41.03 & 5 & 12.82 \\
\hline Average & 21 & 53.85 & 29 & 74.36 \\
\hline Poor & 0 & 0.00 & 4 & 10.26 \\
\hline Very Poor & 0 & 0.00 & 0 & 0.00 \\
\hline Total & 39 & $100 \%$ & 39 & $100 \%$ \\
\hline
\end{tabular}

Table 4 displays the frequency and percentage of posttest scores of the participants in the authentic and pedagogic group after conducting the treatments. From this Table, it was clearly seen that 2 participants (5.13\%) in the authentic group could reach very good score while only 1 participant $(2.56 \%)$ could reach such a score in the pedagogic group. Furthermore, a larger frequency and percentage of the participants in the authentic and pedagogic group gained average score. There were 21 participants $(53.85 \%)$ in authentic group and 29 participants $(74.36 \%)$ in pedagogic group got that score. In fact, 16 the participants $(41.03 \%)$ in authentic group were able to reach good score. On the other hand, in the pedagogic group, there were only 5 participants $(12.82 \%)$ who could obtain good score and there were 4 participants 
(10.26\%) who still got poor score. Based on the findings, it could be assumed that the reading comprehension achievement of participants in the authentic and pedagogic group after conducting the treatments were different and totally developed.

The researcher also presented the mean scores and standard deviation of the participants' posttest scores in Table 5 in order that the data as to the participants' reading comprehension achievement were more noticeable.

Table 5. the Mean Score and Standard Deviation of Participants' Posttest Scores

\begin{tabular}{ccc}
\hline Group & Mean Score & Standard Deviation \\
\hline Authentic & 71.51 & 7.52 \\
\hline Pedagogic & 63.33 & 8.00 \\
\hline Difference & 8.57 & \\
\hline
\end{tabular}

As can be seen in Table 5, the posttest mean score of the authentic group (MS=71.51, $\mathrm{SD}=7.52)$ which was categorized as good was higher than posttest mean score of the pedagogic group which was categorized as average $(\mathrm{MS}=63.33, \mathrm{SD}=8.00)$ and the difference is 8.57 points. Hence, it can be concluded that the results approved the significant impact of using authentic materials in developing reading comprehension achievement of Indonesian EFL students in the authentic group.

After examining the data through normality test in order to determine whether the data had to be tested through parametric or nonparametric, the researcher analyzed t-test for independent sample test using SPPS version 20.0. It aimed to know the significant differences between reading comprehension achievement of the participants in the authentic and pedagogic group. The results can be seen in Table 6 :

Table 6. The P-value of T-test of the Participants' Score in Authentic and Pedagogic Group

\begin{tabular}{cccc}
\hline Variables & P-value & (a) & Remarks \\
\hline Pretest & 0.858 & 0.05 & Not Significantly Different \\
Posttest & 0.000 & 0.05 & Significantly Different \\
\hline
\end{tabular}

As reported in Table 6, it was found that p-value of pretest in the authentic and pedagogic group was 0.858 , while the $p$-value of posttest was 0.00 with the degree of freedom were 76 . It means that the $p$-value of pretest in both groups was greater than the level of significance which was 0.05 (0.858<0.05). Consequently, null hypothesis (H0) was accepted and alternative hypothesis (H1) was rejected. In other words, there were no significant differences between the reading comprehension achievement of participants in the authentic and pedagogic group before the treatments were applied. Meanwhile, based on participants' performance on the posttest both authentic and pedagogic group, it found that $p$-value was 0.000. It was smaller than the level of significance which was $0.05(0.000<0.05)$. This proved that alternative hypothesis $\left(\mathrm{H}_{1}\right)$ was accepted and null hypothesis $\left(\mathrm{H}_{0}\right)$ was rejected. Therefore, it can be concluded that using authentic materials were significantly effective in developing reading comprehension achievement of Indonesian EFL students.

These results seem to be consistent with Desitarahmi's (2013) study. She did an action research at SMP 15 Yogyakarta and she found that the use of authentic materials was effective to improve the students' reading comprehension. The use of these materials was effective when they were used together with authentic tasks which provide communicative activities. Marzban (2015) also found similar result when he conducted a research at intermediate level of proficiency. His result showed that reading authentic texts had positive effect on the reading comprehension of intermediate students.

\subsection{The Reading Motivation Development of Indonesian EFL Students}

In order to investigate the participants' reading motivation in the authentic group, the researcher used MRQ which was consisted of 32 items divided into seven domains of reading motivation which was run before and after participants were given treatments. After analyzing the result of MRQ, the researcher gained the data as can be seen in Table 6.

Table 7. the P-value of T-test of the Participants' Reading Motivation in Authentic Group

\begin{tabular}{|c|c|c|c|c|c|c|}
\hline & & \multicolumn{2}{|c|}{ Paired Differences } & \multirow[b]{2}{*}{$t$} & \multirow[b]{2}{*}{$d f$} & \multirow[b]{2}{*}{ Sig. (2-tailed) } \\
\hline & & Mean & Std. Deviation & & & \\
\hline Pair 1 & $\begin{array}{l}\text { before } \\
\text {-after }\end{array}$ & $-779,4$ & 494,804 & $-9,838$ & 38 &, 000 \\
\hline
\end{tabular}

A paired samples t-test was run In order to see the significant differences between the reading motivation of the participants in the authentic group before and after treatments was conducted. As shown in Table 7, p-value of reading motivation of participants was 0.000 with degree of freedom was 38. It indicated that the p-value of reading was smaller than the level of significance which was 0.05 $(0.000<0.05)$. In other words, there were significant differences between the reading motivation before and after the participants treated using authentic materials. These findings pointed out that the authentic materials had an effect on the reading motivation of Indonesian EFL students.

To support the previous findings, the researcher also explored the development of each domain of motivation by comparing the mean score as presented in Table 8 . 
Table 8. the Rate percentage of Reading Motivation

\begin{tabular}{lcccc}
\hline \multirow{2}{*}{ Domains of Reading } & \multicolumn{2}{c}{ Before Treatments } & \multicolumn{2}{c}{ After Treatments } \\
\cline { 2 - 5 } & Mean & SD & Mean & SD \\
\hline Efficacy & 7.74 & 2.50 & 10.95 & 1.64 \\
Challenge & 12.21 & 2.21 & 13.92 & 1.77 \\
Curiosity & 14.05 & 3.07 & 16.79 & 2.42 \\
Involvement & 15.51 & 3.55 & 17.59 & 0.11 \\
Grades & 10.90 & 1.39 & 10.03 & 2.15 \\
Competition & 12.97 & 1.65 & 11.92 & 2.65 \\
Work Avoidance & 7.97 & 1.84 & 7.85 & 1.77 \\
\hline
\end{tabular}

As exposed in Table 8. from the seven domains of reading motivation, the participants in authentic group had positive changes on means of four domains when the questionnaire was given to them after treatments. The students had an increase in reading efficacy, reading challenge, reading curiosity, reading involvement, and decrease in reading work avoidance, competition on reading, and reading for grades. Finally, it can be concluded that the use of authentic materials was significantly effective in developing reading motivation of Indonesian EFL students.

For more detail, the positive changes on the means of reading motivation of the participants during the research can be seen in Figure 1.

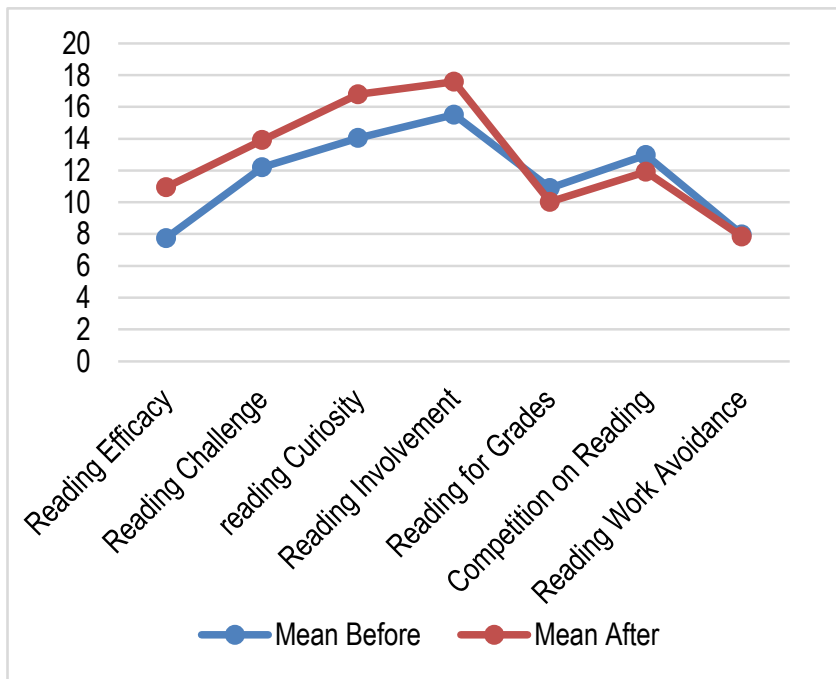

Figure 1, the Development for Each Domain of Reading Motivation

Regarding to the finding about the reading motivation of the participants in authentic group, it indicated an increase on the mean of reading curiosity. It means that after reading authentic texts, students became more motivated to read about their own favorite topics and new things. Reading efficacy is another domain of motivation which had an increase. Here, the focus of reading is on the content in which readers make an interaction with the text, and not on the linguistic features of the text. The participants in the authentic group also had a reduction on the reading for grades. It is clear that the intensity of reading for grades reduced on the post-test and motivation for reading texts with real aims increased. After reading authentic materials, the goal of the students for reading changed. As a result, it can be concluded that the use of authentic materials in teaching reading comprehension significantly developed reading motivation of the Indonesian EFL students.

This result is in line with Al Asri and Al Rashdi' (2014) study. They found that the use of authentic materials is considered a useful means to motivate students, arouse their interest and expose them to the real language in the world. Shao-cing Guo (2012) found a similar result. He examined the effect of reading toward authentic materials. His study showed evidence of vocabulary gain and motivation increase, the students also became more involved in class discussion. This result is supported by Grellet (1996) and Klickaya's (2004) idea stated that authentic materials can be motivating and interesting, or they have a positive effect on students ' interest. In addition, Peacock (1997) also claimed that there are some benefits of applying authentic materials in the classroom, they are: original, interesting, motivating and useful.

\section{CONCLUSION}

The research result shows that the reading comprehension achievement of students developed after learning reading comprehension by using authentic materials. This finding indicates that the use of authentic materials is effective to develop reading comprehension achievement of Indonesian EFL students.

The finding also points out that Indonesian EFL students who are taught through authentic materials became more motivated to read. The result shows that the application of authentic materials is effective to develop students' reading motivation. This is in line with the students' reading comprehension achievement that significantly developed after learning through authentic materials. Hence, it can be said that the higher the students' motivation, the better the students' achievement in reading comprehension and vice versa.

In relation to the conclusion above, the researcher puts forwards some suggestions as follows: (1) The English teachers are highly recommended to use authentic materials in teaching reading comprehension because it was proven as effective ways to develop students' reading comprehension achievement and students' reading motivation. (2) The researchers who want to conduct a similar research, they should select the authentic materials properly. Besides, the materials need to be used with appropriate activities and also pay attention with Teachers' experiments in providing warm-up, Pre-post reading questions, time devotion for teaching reading in the classroom, and the way of giving feedback when the students encounter a problem during reading, all can have an effect on the reading comprehension of the students. (3) The future researcher are also suggested to conduct a research about the use of authentic materials that explores its effect on other linguistic aspects like writing and listening at other level of students for the improvement of 
English teaching, because the use of authentic materials was proven as a ways to give students more exposure of English language, increase motivation and also class interaction. Through reading authentic materials, the students can also learn new vocabulary and culture. While they learn, they can also experience the language in the real world beyond the classroom, so they can study effectively.

\section{REFERENCES}

Al Azri Rashid M. and Al Rashdi Majid H. (2014). The Effect of Using Authentic Materials in Teaching. International Journal of Scientific and Technology Research, Vol, 3 Issue 10.

Berardo, S.A. (2006). The Use of Authentic Materials in the Teaching of Reading. The Reading Matrix Vol.6. No.2. Page. 60-767.

Daar, G. F. (2019). Students' English Language Learning Strategy and Implication to the Teaching and Learning Activity: A Study at Health Vocational Schools (SMK Kesehatan) in Ruteng at Flores. International Journal for Educational and Vocational Studies, 1(6). 564-572.

Desitarahmi, R. (2013). Using Authentic Materials to Improve Reading Comprehension of Grade Eight Students of SMP 15 Yogyakarta. Unpublished Thesis. Undergraduate Program of UNJ.

Fitriani, F., Nur, R. H., Bustamin, B., Ali, S. M., \& Nurisman, N. (2019). Improving Students' Descriptive Text Writing by Using Writing in the Here and Now Strategy at the Tenth Grade Students of Vocational High School. International Journal for Educational and Vocational Studies, 1(6), 632-636.

Grellet, F. (1996). Developing Reading Skills. Cambridge: Cambridge University Press.

Guo, S. (2012). Using Authentic Materials for Extensive Reading to Promote English Proficiency. Taiwan. Canadian Center of Science and Education. 196-206.

Hasriani. (2013). Using Folktales with Pictures in Improving Students' Writing at SMP 10 Makassar. Unpublished Thesis. Graduate Program of UNM.

Kilickaya. F. (2004). Authentic materials and cultural content in EFL classrooms. The Internet TESL Journal, $10(7)$.

Marzban, Amir. (2015). The Effect of Authentic Texts on Motivation and Reading Comprehension of EFL Students at Intermediate Level of Proficiency. Theory and Practice in Language Studies, Vol. 5, No. 1, pp. 85-91.

Marzuki, M. (2019). Common Mistakes Found in Essay Writing of Chemical Engineering Department First Grade Students in Politeknik Negeri Lhokseumawe. International Journal for Educational and Vocational Studies, 1(6). 591-594.
Melvin, B.S. and Stout, D.S. (1987). Motivating language learners through authentic materials. In: W. Rivers (ed.) Interactive Language Teaching. New York: Cambridge University Press.

Nunan, D. (1989). Designing Task for The Communicative Classroom. New York: Cambridge University Press.

Noviandari, H., \& Mursidi, A. (2019). Relationship of Self Concept, Problem Solving and Self Adjustment in Youth. International Journal for Educational and Vocational Studies, 1(6). 651-657.

Peacock, M. (1997). The Effect of Authentic Materials on the Motivation of EFL Learners in English. Language Teaching Journal. Volume 51 (2).

Richards, Jack C. (2001). Longman Dictionary of Applied Linguistics. England: Longman House.

Wigfield, A., \& Guthrie, J.T. (1997). Relations of children's motivation for reading to the amount and breadth of their reading. Journal of Educational Psychology, 89, 420-432. 